\title{
Seasonal dynamics of methane cycling microbial communities in Amazonian
}

\section{floodplain sediments}

Júlia B. Gontijo ${ }^{a^{*}}$ Andressa M. Venturini ${ }^{a}$, Caio A. Yoshiura ${ }^{a}$, Clovis D. Borges ${ }^{a}$, José Mauro S. Moura ${ }^{b}$, Brendan J. M. Bohannan ${ }^{c}$, Klaus Nüsslein ${ }^{d}$, Jorge L. Mazza Rodrigues ${ }^{\text {ef }}$, Fabiana S. Paula ${ }^{a^{*}} ;$ Siu M. Tsai ${ }^{\mathrm{a}}$

${ }^{\mathrm{a} C e l l}$ and Molecular Biology Laboratory, Center for Nuclear Energy in Agriculture, University of São Paulo. Piracicaba, SP, Brazil;

${ }^{\mathrm{b}}$ Federal University of Western Pará, Santarém, PA, Brazil;

'Institute of Ecology and Evolution, Department of Biology, University of Oregon, Eugene, OR, United States;

dDepartment of Microbiology, University of Massachusetts, Amherst, MA, United States;

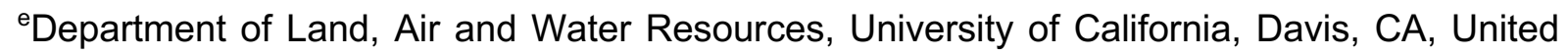
States of America;

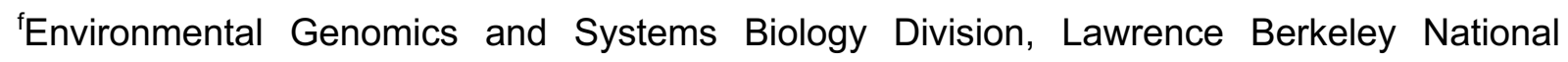
Laboratory, Berkeley, CA, United States of America.

JBG: Orcid \# 0000-0003-1942-7242

AMV: Orcid \# 0000-0002-5901-1658

CAY: Orcid \# 0000-0002-1016-6456

CDB: Orcid \# 0000-0003-0992-3162

JMSM: Orcid \# 0000-0003-4962-8870

BJMB: Orcid \# 0000-0003-2907-1016

KN: Orcid \# 0000-0002-0663-4448

JLMR: Orcid \# 000-0002-6446-6462

FSP: Orcid \# 0000-0002-0010-1552 
SMT: Orcid \# 0000-0002-3733-6312

\section{"Corresponding authors:}

E-mail: juliabrandao@usp.br

\section{3 \\ Fabiana S. Paula}

E-mail: fabianapaula@usp.br

Cell and Molecular Biology Laboratory, Center for Nuclear Energy in Agriculture, University of

São Paulo. Avenida Centenário, 303, Piracicaba, SP, 13416-000, Brazil.

\section{Abstract}

The Amazonian floodplain forests are dynamic ecosystems of great importance for the regional hydrological and biogeochemical cycles and provide a significant contribution to the global carbon balance. Unique geochemical factors may drive the microbial community composition and, consequently, affect $\mathrm{CH}_{4}$ emissions across floodplain areas. Here we provide the first report of the in situ seasonal dynamics of $\mathrm{CH}_{4}$ cycling microbial communities in Amazonian floodplains. We asked how abiotic factors may affect both overall and $\mathrm{CH}_{4}$ cycling microbial communities and further investigated their responses to seasonal changes. We collected sediment samples during wet and dry seasons from three different types of floodplain forests, along with upland forest soil samples, from the Eastern Amazon, Brazil. We used highresolution sequencing of archaeal and bacterial 16S rRNA genes combined with real-time PCR to quantify Archaea and Bacteria, as well as key functional genes indicative of the methanogenic (methyl coenzyme-M reductase - mcrA) and methanotrophic (particulate methane monooxygenase $-p m o A$ ) metabolisms. Methanogens were found to be present in high abundance in floodplain sediments and they seem to resist to dramatic seasonal 
detected, including anaerobic archaeal and bacterial taxa, indicating that a wide metabolic diversity may be harboured in this highly variable environment. The floodplain environmental variability, which is affected by the river origin, drives not only the sediment chemistry, but also the composition of the microbial communities. The results presented may contribute to the understanding of the current state of $\mathrm{CH}_{4}$ cycling in this region.

Keywords: Tropical wetlands; Methanogens; Methanotrophs; 16S rRNA sequencing; Quantitative PCR.

\section{Introduction}

In the Amazon region, floodplain forests occupy an area of about $800,000 \mathrm{Km}^{2}$ (Hess et al., 2015). These ecosystems comprise diversified and dynamic landscapes, which are exposed to seasonal flooding events by the expanding rivers, as a consequence of the periodic excessive rainfalls. Floodplains seem to play a significant role in the regional and global $\mathrm{C}$ budget (Junk, 1997; Moreira-Turcq, Seyler, Guyot \& Etcheber, 2003; Pangala et al., 2017; Gedney, Huntingford, Comyn-Platt \& Wiltshire, 2019). While uplands forests are considered important tropical methane $\left(\mathrm{CH}_{4}\right)$ sinks, floodplains represent the largest natural sources of $\mathrm{CH}_{4}$ into the atmosphere (Conrad, 2009; Meyer et al. 2017; Gedney et al., 2019), including the significant process of $\mathrm{CH}_{4}$ transfer through trees (Pangala et al., 2017). Modelling studies have predicted that Amazonian floodplains may contribute up to $7 \%$ of total global $\mathrm{CH}_{4}$ emissions (Potter, Melack \& Engle, 2014; Wilson et al., 2016).

In anoxic environments, the $\mathrm{CH}_{4}$ is generated as the final product of the anaerobic respiration by methanogenic archaea, which can use acetate, $\mathrm{H}_{2} / \mathrm{CO}_{2}$, formate, $\mathrm{CO}$, or methylated compounds as substrates (Bridgham, Cadillo-Quiroz, Keller \& Zhuang, 2013). The ability to use one or more substrates varies across the different methanogenic archaea taxa. Hence, substrate availability, along with other factors (biotic and abiotic), affects the diversity of these organisms in the environment (Barros et al., 2019). 
In ecosystems that are sources of $\mathrm{CH}_{4}$, methanotrophs are particularly important for oxidising the $\mathrm{CH}_{4}$ and, therefore, attenuate net fluxes of this greenhouse gas into the atmosphere (Conrad, 2009; Ho et al., 2013). Aerobic methanotrophic bacteria can occur in terrestrial and aquatic environments, mainly at oxic/anoxic interfaces, where oxygen $\left(\mathrm{O}_{2}\right)$ is available as an electron acceptor and $\mathrm{CH}_{4}$ as an energy and carbon source (Knief, 2015). In addition, the anaerobic oxidation of $\mathrm{CH}_{4}$ plays an important role in mitigating emissions of this greenhouse gas, and several types of this metabolism have been discovered in the recent years. However, the biochemical mechanisms performed by representatives of the Archaea (Nazaries, Murrell, Millard, Baggs, \& Singh, 2013; Serrano-Silva, Sarria-Guzmán, Dendooven, \& Luna-Guido, 2014) and Bacteria (Shen, Wu, Gao, Liu, \& Li, 2016) are still vastly unknown (Scheller et al., 2020).

Despite the important role of the Amazonian floodplain forests for the global $\mathrm{CH}_{4}$ emissions (Sawakuchi et al., 2014, Gedney et al., 2019), the composition of their respective microbial communities remains mostly unexplored. A few studies have attempted to describe these communities (Conrad, Klose, Claus \& Enrich-Prast, 2010; Conrad et al., 2011; Ji et al., 2016; Sawakuchi et al., 2016). Recently, using a microcosm experiment, Hernández et al. (2019) showed that methanogens are present in high abundance in Amazonian floodplain sediments regardless of the incubation conditions, while their abundance in upland forest soils increases only upon anaerobic incubation. Nevertheless, to date, there was no effort to characterise the seasonal dynamics of the methanogenic and methanotrophic groups in situ. In addition, the environmental variability present in floodplain ecosystems is likely to result in major differences in the $\mathrm{CH}_{4}$ cycling communities not only in temporal, but also in spatial scales. For instance, the riverine origin is a very important factor, as some waters may carry large amounts of inorganic suspensoids, such as the Amazon river, while others are comparatively poor in dissolved solids, such as the Tapajós river (Junk et al., 2011).

Here we provide the first in-depth characterisation of microbial communities responsible for $\mathrm{CH}_{4}$ cycling in Amazonian floodplain sediments and their seasonal dynamics 
in situ. We selected three floodplain areas with contrasting characteristics to explore part of the vast environmental variability found in this ecosystem. We asked how the abiotic factors inherent of each area may affect microbial community composition and further investigated season-driven changes. In addition, to examine the same seasonal dynamics in an area without flooding influences, an upland forest site was also studied. To tackle these questions, we used high-resolution sequencing of the 16S rRNA genes to assess archaeal and bacterial diversities, along with the quantification of key genes in the $\mathrm{CH}_{4}$ production (methyl coenzyme$\mathrm{M}$ reductase $-m c r A$ ) and oxidation (particulate methane monooxygenase - pmoA). The results highlight the importance of the local environmental factors to drive both chemistry and microbiology of the floodplain forests. This information is of great relevance for the understanding of the current state of the regional $\mathrm{CH}_{4}$ cycle and to predict future scenarios under climate change influence.

\section{Methods}

\section{Sediment and soil sampling}

The studied sites are located in the region of Santarém and Belterra, in the centralwestern parts of the state of Pará, Brazil. The regional climate is classified as Am (Köppen), tropical humid, with a mean annual temperature of $26 \pm 2{ }^{\circ} \mathrm{C}$, and annual precipitation above 2,500 mm (Alvares, Stape, Sentelhas, Gonçalves \& Sparovek, 2013). There are two well defined seasons, dry (DS; July - November) and wet (WS; December - June), with more than $70 \%$ of the rain concentrated in the latter.

Triplicate sediment samples were collected from three floodplain areas in May (WS) and October (DS) 2016, when the rivers reached maximum and minimum levels, respectively. These areas differed regarding their vegetation (Moura et al. 2008) and the adjacent river: FP1 (Floodplain 1 at Igarapé Jamaraquá, S2 49.077 W55 02.077), in the Tapajós river; FP2 (Floodplain 2 at Igarapé Maicá, S2 28.186 W54 38.831), in the Amazonas river; and FP3 
135 (Floodplain 3 at Igarapé Açu, S2 22.747 W54 44.352), in the intersection of both rivers. In

136 addition, we collected soil samples from an upland primary forest area, PFO (S2 51.326 W54

137 57.501), located in the Tapajós National Forest.

138 Sediment and soil samples were collected using a corer (5 cm diameter $X 10 \mathrm{~cm}$ depth)

139 and transported on ice to the laboratory. All samples were homogenised thoroughly and stored

$140 \quad\left(-20{ }^{\circ} \mathrm{C}\right.$ for DNA analyses and $4{ }^{\circ} \mathrm{C}$ for chemical analyses $)$ and processed within two weeks.

141 During the wet season, the water column in the floodplains ranged from 0.5 to $3 \mathrm{~m}$. Dissolved

142 oxygen (DO) and $\mathrm{pH}$ in the sediment-water interface were assessed using a YSI Professional

143 Plus Instrument (Pro Plus, Yellow Springs, OH, USA). No water column was observed during

144 the dry season sampling, however, site FP1 was water-logged.

145

146

147

148

149

150

151

152

153

154

155

\section{Chemical analyses}

Sediment and soil samples were processed in the Laboratory of Chemical Analysis of the Department of Soil Science of the Luiz de Queiroz College of Agriculture (ESALQ/USP, Brazil), following procedures described by Camargo, Moniz, Jorge, \& Valadares (2009). The following parameters were determined: $\mathrm{pH}$ in $\mathrm{CaCl}_{2}$; total nitrogen $(\mathrm{N})$ by Kjeldahl method; phosphorus $(\mathrm{P})$, potassium $(\mathrm{K})$, calcium $(\mathrm{Ca})$ and magnesium $(\mathrm{Mg})$ by ion exchange resin extraction; sulphur (S) by calcium phosphate $0.01 \mathrm{~mol} \mathrm{~L}^{-1}$ extraction and turbidimetry determination; aluminium (Al) extraction by potassium chloride extraction $1 \mathrm{~mol} \mathrm{~L}^{-1}$; organic matter (OM) by the dichromate/titrimetric method; boron (B) by extraction with hot water; and the micronutrients copper $(\mathrm{Cu})$, iron $(\mathrm{Fe})$, manganese $(\mathrm{Mn})$ and zinc $(\mathrm{Zn})$ with a chelating agent, according to Lindsay and Norvell (1978).

\section{DNA extraction}

The extraction of DNA from $0.25 \mathrm{~g}$ of sediment and soil samples was carried out in duplicate reactions using the PowerLyzer PowerSoil DNA Isolation Kit (MoBIO Laboratories Inc., Carlsbad, CA, USA), with an optimised protocol for tropical soils described by Venturini 
162

163

et al. (2020). Briefly, the adaptations included an extension in the vortex time to $15 \mathrm{~min}$, followed by a 3 min centrifugation at $10,000 \times g$ and incubation with $\mathrm{C} 2$ and $\mathrm{C} 3$ solutions at $20{ }^{\circ} \mathrm{C}$. DNA quantity and quality were assessed in $1 \%$ agarose gel and using a Nanodrop 2000c spectrophotometer (Thermo Fisher Scientific Inc., Wilmington, DE, USA) set for determining absorbance at the following wavelengths: 230, 260, 280 and $320 \mathrm{~nm}$. Purified DNA samples were stored at $-20^{\circ} \mathrm{C}$ until processed.

\section{Archaeal and bacterial 16S rRNA gene sequencing}

The diversity of archaeal and bacterial communities was assessed by high-throughput sequencing of the V4 region of 16S rRNA gene, using the following primer sets, respectively: 519f/915r (Klindworth et al., 2013; Stahl \& Amman, 1991) and 515f/806r (Caporaso et al., 2011). Paired-end sequencing, with $2 \times 250$ bp reads, was performed in Illumina Hiseq 2500 platform, at Novogene Bioinformatics Technology (Beijing, China), using standard procedures.

\section{Quantitative PCR}

Quantitative PCR (qPCR) was used to assess the abundance of archaeal and bacterial $16 \mathrm{~S}$ rRNA genes, as well as functional gene markers for the methanogenic (methyl coenzyme$\mathrm{M}$ reductase $-\mathrm{mcrA}$ ) and methanotrophic (particulate methane monooxygenase - pmoA) metabolisms. Cycle conditions and primers used are described in the Supporting Information Table S1. The $10 \mu \mathrm{l}$ reactions contained $5 \mu \mathrm{l}$ of SYBR Green ROX qPCR (Thermo Fisher Scientific Inc., Wilmington, DE, USA), $0.2 \mu \mathrm{l}$ of bovine serum albumin (Thermo Fisher Scientific Inc., Wilmington, DE, USA, $\left.20 \mathrm{mg} \mathrm{ml}^{-1}\right), 1 \mu \mathrm{l}$ of each primer (5 pmol), $1 \mu$ l of DNA template (10 $\mathrm{ng}$ ) and $1.8 \mu \mathrm{l}$ of ultrapure water. Reactions were performed in triplicate using a StepOne Plus instrument (Applied Biosystems, Foster City, CA, USA). Gene abundance was estimated using a standard curve constructed with $10^{0}$ to $10^{10}$ copies of the targeted gene fragments amplified from the strains presented in Supporting Information Table S1. 
189

\section{Bioinformatics and statistical analyses}

All bioinformatics and statistical analyses were performed on R studio 3.5 .1 (Rstudio Team, 2018). Raw sequences were analysed by inferring the amplicon sequence variants (ASVs) using the Dada2 1.9.3 package (Callahan et al. 2016). We obtained approximately 1.3 $\mathrm{M}$ sequences of Archaea and 4.1 M sequences of Bacteria. Reads with phred score $>30$ were truncated at the positions 220 and 180 for Archaea and 200 and 190 for Bacteria. Sequences were error-corrected, dereplicated, merged and chimera-filtered. After quality control, 700,396 archaeal sequences with an average length of $383 \mathrm{bp}$, and 3,054,201 bacterial sequences with an average length of 253 bp were obtained. Taxonomy was assigned using the SILVA database (release 132, 12.13.2017). The ASV counts classified in the same taxonomic groups were summarised and normalised to within-sample relative abundance.

Statistical analyses and graphical visualisation were carried out using vegan 2.5-1 (Oksanen et al., 2018), ARTool 0.10.5 (Kay \& Wobbrock, 2018), dunn.test 1.3.5 (Dinno, 2017), Hmisc 4.1-1 (Harrel, 2018), corrplot 0.84 (Wei \& Simko, 2017) and ggplot2 3.1 .0 (Wickham \& Chang, 2016) packages. The methanogenic and methanotrophic taxa were filtered and grouped at the family level using the databases PhyMet2 (http://phymet2.biotech.uni.wroc.pl/) and Methanotroph Commons (http://www.methanotroph.org/wiki/taxonomy/), respectively. Shapiro-Wilk normality test and Levene's homogeneity test were performed in order to define the most appropriate statistical test to be used to detect significant differences among treatments. Non-Metric Multidimensional Scaling (NMDS) and Analysis of Similarities (ANOSIM) were used to assess the similarities among samples regarding chemical properties (Euclidean distance) and community composition (Bray-Curtis distance). Envfit analysis was also carried out aiming to find the environmental variables related to the microbial community structure. Kruskal-Wallis with post-hoc Dunn's test was used to determine statistical differences among the chemical properties of the studied areas. Two-way ANOVA of aligned rank transformed data (aiming to perform a non-parametric test using a parametric method) was used to investigate the effect of season and location on the relative abundance of $\mathrm{CH}_{4}$ 
cycling related taxa and functional gene quantities in the floodplains. The correlations among chemical properties, the relative abundance of taxonomic groups and qPCR data were performed and assessed using Spearman's correlation coefficient.

\section{Results}

\section{Seasonal changes in chemical properties} when compared to FP2 and FP3. Forest (PFO) soils presented higher OM and N contents in relation to the floodplains (Supporting Information Table S2). Multivariate analysis of the chemical profiles indicated significant differences among sites (Figure 1; Supporting Information Table S3). By contrast, no significant season effect was observed for any site.

\section{Archaeal and bacterial communities}

Analysis of similarities (Table 1) and NMDS ordination (Figure 2a) indicated no significant difference in the composition of the archaeal community among the three floodplain sites, albeit FP1 tended to form a separated cluster. $\mathrm{pH}$ and $\mathrm{Mn}$ correlated positively with the community composition in floodplain sites, while $\mathrm{B}, \mathrm{N}$ and $\mathrm{OM}$ were correlated with forest soil communities (Supporting Information Table S4). Crenarchaeota and Thaumarchaeota were the dominant phyla in all floodplain sites (relative abundance average above 30\%).

235 Nanoarchaeota also presented high relative abundance in FP1 (average 16\%), while 236 Euryarchaeota were among the dominant phyla in FP2 and FP3, comprising the average of 23718 and $26 \%$ of the archaeal communities, respectively. By contrast, major differences were 238 observed between archaeal communities from forest soils and floodplain sediments. In the 239 forest soils, the phylum Thaumarchaeota represented $>92 \%$ of the archaeal communities (Supporting Information Figure S1a)

The composition of the bacterial communities was found to be significantly different 242 across all sites (Figure 2b, Table 1). Although the bacterial communities from FP1 showed 
correlation only with $\mathrm{pH}, \mathrm{FP} 2$ and FP3 were associated with increasing concentrations of Al, $\mathrm{Ca}, \mathrm{Mn}, \mathrm{Zn}, \mathrm{Mg}, \mathrm{K}, \mathrm{Cu}$ and $\mathrm{P}$ (Supporting Information Table S4). Despite oscillations in relative abundance, the same phyla composed the dominant communities across all sites: Proteobacteria, Actinobacteria, Acidobacteria, Chloroflexi and Firmicutes (Supporting Information Figure S1b).

The abundance of archaea and bacteria in the samples was assessed by qPCR. Standard curves presented $\mathrm{R}^{2}$ values above 0.99 and amplification efficiencies between $75 \%$ and $99 \%$. The average abundance (gene copies ng DNA ${ }^{-1}$ ) ranged from $3 \times 10^{3}$ to $4 \times 10^{4}$ for archaeal 16S rRNA, and $3 \times 10^{5}$ to $1 \times 10^{6}$ for bacterial $16 \mathrm{~S}$ rRNA (Supporting Information Figure S2).

No seasonal effect on the overall microbial composition was observed for any site. By contrast, season was found to be a significant factor affecting bacterial abundance, while archaea responded to site $\mathrm{x}$ season interaction (Table 2).

\section{Methanogenic and methanotrophic communities}

We searched the 16S rRNA gene sequence data for taxa with a reported role in $\mathrm{CH}_{4}$ production or consumption. The overall relative abundance of methanogenic archaea in the floodplain sediments varied widely, ranging from 2 to $34 \%$ on average, while it was below $1 \%$ in forest soils (Figure 3a). Methanobacteriaceae was the dominant methanogenic family across all samples, with relative abundance reaching $52 \%$ ( $31 \%$ on average). The relative abundance of Methanobacteriaceae and Methanoperedenaceae changed significantly with site location, but only Methanoperedenaceae and Methanosarcinaceae were significantly affected by season and by site $x$ season interaction (Table 2). In addition, the class Bathyarchaeia, which has been suggested as a methanogenic taxon outside the Euryarchaeota phylum (Evans et al. 2015), was the main Crenarchaeota taxon detected in the floodplains, with a relative abundance ranging from 31 to $52 \%$ from the total archaeal community. 
Methanotrophic taxa represented only a small fraction of the bacterial community. The

271 relative abundance of methanotrophs ranged from 1.5 to $2.7 \%$ in the floodplain sediments,

272 while it was below $0.6 \%$ in the forest soils (Figure 3b). Groups from the Beijerinckiaceae family

273 (Alphaproteobacteria class) and NC10 class (Rokubacteria phylum) were the most abundant

274 methanotrophs in all areas, followed by Methylomonaceae and Methylococcaceae

275 (Gammaproteobacteria class). Only Methylomonaceae changed significantly across sites and

276 seasons, while all other methanotrophic families were not affected by both factors (Table 2).

277 When we assessed the abundance of the gene markers for methanogenesis (mcrA)

278 and methanotrophy $(p m o A)$, the patterns observed above were confirmed: in floodplain

279 sediments, regardless of the season, there was a higher abundance of methanogens and

280 methanotrophs in comparison to forest soil (Figure 4a and 4b). The mcrA gene abundance

281 ranged from $2 \times 10^{3}$ to $5 \times 10^{3}$ copies ng DNA ${ }^{-1}$ in the floodplain sediments, while in the forest

282 soils, it was below the detection limit. Gene counts for pmoA in floodplain sediments ranged

283 from $1 \times 10^{2}$ to $4 \times 10^{2}$ copies ng DNA ${ }^{-1}$, while forest soils presented less than $5 \times 10^{1}$ copies

284 ng $\mathrm{DNA}^{-1}$. Considering only the floodplains, the abundance of the mcrA gene was not

285 significantly affected by area or season, while pmoA varied with season (Table 2). This pattern

286 was also observed in the mcrA:pmoA ratio, which tended to decrease in the dry season (Table

287 2; Figure 4c).

288 To search for correlations between $\mathrm{CH}_{4}$ cycling microbes and abiotic factors in the

289 floodplains, we used the Spearman coefficient. Figure 5 shows significant $(p<0.05)$ positive

290 and negative correlations observed for floodplain areas across seasons. The pmoA gene

291 abundance was strongly correlated with DO during the wet season. The $\mathrm{pH}$ value was

292 positively correlated with the relative abundance of Methanomassiliicoccaceae, and negatively

293 correlated with Methanobacteriaceae, Methanoperedenaceae and NC10. Methylomonaceae

294 was positively correlated with OM, while Methanobacteriaceae and Methanoperedenaceae

295 correlated with $\mathrm{N}$ and $\mathrm{P}$. Interestingly, Methanoperedenaceae also showed a positive

296 correlation with Mn contents. 


\section{Discussion}

The Amazon river, termed "white-water", transports large amounts of nutrient-rich sediments, which are carried to the floodplain forests during the raining season. By contrast, the Tapajós river, termed "clear-water", delivers low amounts of sediments and dissolved solids (Junk et al., 2011). The transfer of materials by the Amazon river to sediments at sites FP2 and FP3 was indicated by their higher contents of trace metals, such as $\mathrm{Cu}, \mathrm{Mn}$ and $\mathrm{Zn}$. As a consequence, these sites presented a higher chemical similarity to each other, when compared to FP1, which is exposed exclusively to the Tapajós river. In fact, FP1 clustered separately from the other floodplains, suggesting that due to the low nutrient content of the Tapajos, forest-related factors may have a stronger influence on the chemical composition of these sediments.

In the Amazon region, several studies already showed the importance of soil chemical properties on the soil microbial community composition (Rodrigues et al. 2013) and function (Paula et al. 2014; Lammel, Feigl, Cerri, \& Nüsslein, 2015). Here we show that archaeal and bacterial communities in sediments from the three floodplains analysed are significantly distinct from upland forest soil communities regarding their composition. In addition, we observed major differences among floodplain areas with distinct environmental characteristics. This information is valuable to detangle which environmental factors drive the variations in microbe-driven ecosystem processes. It is interesting that the archaeal and bacterial communities from the FP1 did not cluster together with upland forest soil communities. This might indicate that flooding is a major determinant of the composition of the microbial communities in the floodplain forests, and also that environmental factors not assessed in this study are likely to be affecting these communities.

Our data indicated that the composition of the microbial communities did not change with season, although this factor affected the abundance of archaea and bacteria. Microbes are known for their high degree of metabolic flexibility and physiological adaptations that may allow them to endure under changing environmental conditions (Meyer, Lipson, Martín, 
Schadt, Schmidt, 2004; Ye et al., 2018). The periodic flooding events may favour microbial taxa that are adapted to these environmental oscillations. contrast, in the floodplains, Euryarchaeota and Crenarchaeota were also among the dominant groups. To date, all isolates of methanogenic archaea belong to the phylum Euryarchaeota (Evans et al., 2019). However, recent metagenomic studies have suggested that the class Bathyarchaeia (representing $>99 \%$ of Crenarchaeota in our study) may have a potential

331 function in $\mathrm{CH}_{4}$ production and consumption (Evans et al., 2015). The role of Bathyarchaeia in 332 the $\mathrm{CH}_{4}$ cycle is yet to be clarified, but the presence of genes related to other steps in the anaerobic degradation of organic matter in their genomes, including acetogenesis (He et al. 2016), indicates that this group may have an important role in anaerobic environments, such as floodplain sediments.

We also observed a higher relative abundance of the class Wosearchaeia (representing $>99 \%$ of Nanoarchaeota) in FP1, in relation to the other floodplain areas. Although scant information is available for this class, studies have suggested that some groups may establish syntrophic interactions with methanogens and provide metabolic complementation (Liu et al., 2018). This might indicate a potential role of this group in the $\mathrm{CH}_{4}$ cycle of FP1, which has oligotrophic characteristics, if compared to the other floodplains. Together, Euryarchaeota, Bathyarchaeia and Woesearchaeia represent more than half of the total archaeal community in the floodplains during all seasons, highlighting the importance of

344 the $\mathrm{CH}_{4}$ metabolism in the biogeochemistry of these environments.

Among the methanogens belonging to the Euryarchaeota, Methanobacteriaceae was the dominant family in all areas. This group is widely distributed in anaerobic environments across the globe and is known to produce $\mathrm{CH}_{4}$ mainly through the hydrogenotrophic pathway

348 (Evans et al., 2019). Methanosarcinacea, which accounted only for a small fraction of the methanogens, is a metabolically versatile group and is able to utilise $\mathrm{H}_{2} / \mathrm{CO}_{2}$, acetate, 350 methylamines, and methanol as substrates for methanogenesis (Welander \& Metcalf, 2008; 
351 Fournier, 2009; Evans et al.; 2019). Methanomassiliicoccaceae, which was part of the

352 dominant groups only in FP1, is known as an obligately methylotrophic and hydrogen-

353 dependent methanogen (Nkamga \& Drancourt, 2016). In our study, we observed a prevalence

354 of microbes with the potential to perform the hydrogenotrophic pathway. However, 355 investigations on the RNA level and on the isotopic signal would be required to determine the 356 dominant metabolic route in the Amazonian floodplains. Transcriptional data will also be essential to explain the emission profiles reported for these ecosystems (Angle et al., 2017).

358 At the DNA level, we did not find significant variations in both relative and absolute abundance 359 of methanogens between both seasons. Despite the lack of knowledge in the mechanisms 360 underpinning this process, the resistance of methanogens to drainage was also reported by 361 Ma and Lu (2011). It is likely that those microbes may present protection against oxidative 362 stress, as already reported for methanogens (Angle et al., 2017; Lyu, Shao Akinyemi, \& 363 Whitman, 2018). According to Hernández et al. (2019), the abundance of methanogens could 364 be an indication of the flooding history of the Amazon floodplain. In a microcosm experiment, 365 the authors observed the survival of the methanogenic populations to short, but not to long periods of desiccation.

Regarding the $\mathrm{CH}_{4}$-oxidising microbes, the Type II-b methanotrophs from the Beijerinckiaceae family were found to compose large fractions of the communities and did not seem to be affected by season. These organisms are known to endure under fluctuations in the environment, such as variable $\mathrm{O}_{2}$ and $\mathrm{CH}_{4}$ availability. Their stability is owed to several 371 strategies, including dormancy (Eller, Krüger, \& Frenzel, 2005; Krause, Lüke \& Frenzel, 2012; 372 Ho et al., 2013) and ability to use different carbon substrates (Dedysh, Knief, \& Dunfield, 2005; 373 Dedysh, Haup, \& Dunfield, 2016). Such versatility could confer an advantage in the floodplain 374 environment, which may present not only temporal, but also spatial variation in $\mathrm{CH}_{4}$ availability 375 (Moura et al., 2008). Other groups detected at lower relative abundances, the Methylococcaceae and Methylomonaceae, can use the ribulose monophosphate pathway, 
methanotrophic bacteria are very responsive to high substrate availability, but have their abundance reduced quickly under $\mathrm{O}_{2}$ limitation or other adverse conditions, as the contrasting wet and dry seasons in the Amazon basin. The abundance of methanotrophs (assessed by quantifying the pmoA gene), was affected by seasonality and positively correlated with dissolved $\mathrm{O}_{2}$ during the wet season. The pmoA gene is present in all known Type I metabolic types and also in the anaerobic denitrifying NC10, while it can be present also in some Type II taxa with exceptions among Beijerinckiaceae (Knief, 2015).

The rate of $\mathrm{CH}_{4}$ emission is related to the balance between the activity of methanogens and methanotrophs in the environment (Malyan et al., 2016). Although many studies showed that Amazonian floodplains are an important source of $\mathrm{CH}_{4}$ (Ringeval et al., 2014; Potter et al., 2014; Barbosa et al., 2020), Koschorreck (2000) demonstrated that the $\mathrm{CH}_{4}$ emission rates may decrease to zero when the sediments become exposed to air. In fact, we observed a decrease of mcrA:pmoA ratios during the dry season in all areas. The drainage of the

391 floodplains allows for the oxygenation of the sediment, which could promote an increase in 392 abundance and/or activity of the aerobic methanotrophs in relation to the methanogenic community.

Aerobic $\mathrm{CH}_{4}$-oxidising microorganisms have long been recognised to play an important role in the regulation of $\mathrm{CH}_{4}$ emissions to the atmosphere (Graf et al. 2018). However, in the recent years, anaerobic oxidation of $\mathrm{CH}_{4}(\mathrm{AOM})$ has been shown to be more widespread than previously predicted in areas of high organic matter availability (Evans et al., 2019). In the

398 floodplain sediments, we detected both archaeal and bacterial taxa with the reported capability 399 to carry out anaerobic $\mathrm{CH}_{4}$ oxidation. For instance, the methanogenic family 400 Methanoperedenaceae (Timmers et al. 2017) has been proposed as a potential anaerobic 401 methanotrophic archaeal (ANME) group, using the nitrate-dependent reverse methanogenesis 402 (Yan \& Ferry, 2018) or in consortia with sulphate-reducing bacteria (Su et al., 2019). Here we found a positive correlation between Metanoperedenaceae relative abundance and $\mathrm{Mn}$ 404 contents of the sediment. This could suggest a potential role of these microbes, as it has been 
405

406

407

408

409

410

411

412

413

414

415

416

417

418

419

420

421

422

423

424

425

426

427

428

429

430

431

demonstrated that members of the ANME group, including the Methanoperedenaceae, can be coupled with the dissimilatory reduction of metals, including Mn (Scheller, Yu, Chadwick, McGlynn, \& Orphan, 2016, Leu et al., 2020). The bacterial class NC10, which is among the dominant methanotroph groups detected in this study, has been reported to contain groups that are able to oxidise $\mathrm{CH}_{4}$ under anaerobic conditions using nitrite as an electron acceptor, a process that generates oxygen, which is subsequently used to oxidise $\mathrm{CH}_{4}$ as carbon source (Ettwig et al., 2010; Padilla et al., 2016). This capability provides an advantage for NC10 to thrive in oxygen-depleted environments (Shen et al., 2016). The metabolic diversity and the biogeography of AOM are still largely unknown (Cui, Ma, Qi, Zhuang, \& Zhuang, 2015) and studies providing insights in this field are in high demand. Recently, Gabriel et al. (2020) incubated Amazonian floodplains sediments in anaerobic reactors and observed the presence of AOM coupled with iron reduction. Here we report the in situ presence of archaeal and bacterial taxa with the potential to oxidise $\mathrm{CH}_{4}$ anaerobically in Amazonian floodplains.

We presented the first report on the in situ seasonal dynamics of $\mathrm{CH}_{4}$ cycling microbial communities in three different types of floodplains located in the Eastern Amazon. We observed that methanogens are present in high abundance and they seem to resist the dramatic environmental changes that occur between seasons. Methanotrophs that use different pathways to oxidise $\mathrm{CH}_{4}$ were detected, indicating that a wide metabolic diversity may be harboured in this highly variable environment. This environmental variability, which is remarkably affected by the river origin, drives not only the floodplain sediment chemistry, but also the composition of the microbial communities. In the light of climate change, the data provided in this study may contribute to the understanding of the current state of the $\mathrm{CH}_{4}$ cycling in the Amazonian floodplains, which is essential to predict future scenarios.

\section{Data Accessibility}

16S rRNA sequence data were deposited on NCBI's Sequence Read Archive (SRA) under the accession number PRJNA629547. 
432

433

434

435

436

437

438

439

440

441

442

443

444

445

446

447

448

449

450

451

452

453

454

455

456

457

\section{Author Contributions}

JBG, SMT, BJMB, KN and JLMR designed the research; JBG, AMV, JMSM, and CDB collected the samples; JBG and AMV performed the bench work; JBG and CAY analysed the data; JBG, FSP and SMT wrote the manuscript; all authors contributed to the final manuscript version.

\section{Acknowledgments}

This study was financed in part by the São Paulo Research Foundation (FAPESP grants 2014/50320-4, 2015/13546-7, 2017/26138-0, 2018/14974-0 and 2019/25931-3), National Council for Scientific and Technological Development (CNPq grants 133769/2015-1 and 311008/2016-0), and the Coordination for the Improvement of Higher Education Personnel Brasil (CAPES) - Finance Code 001. We especially thank Wagner Piccinini, Erika B. Cesar, Liana C. Rossi and the ECOFOR and LBA teams for their contribution to the field expeditions.

\section{References}

Alvares, C. A., Stape, J. L., Sentelhas, P. C., Gonçalves, J. L. M., \& Sparovek, G. (2013). Köppen's climate classification map for Brazil. Meteorologische Zeitschrift, 22(6), 711728. doi: 10.1127/0941-2948/2013/0507

Angle, J. C., Morin, T. H., Solden, L. M., Narrowe, A. B., Smith, G. J., Borton, M. A., ... Wrighton, K. C. (2017). Methanogenesis in oxygenated soils is a substantial fraction of wetland methane emissions. Nature Communications, 8(1). doi: 10.1038/s41467-01701753-4

Barbosa, P. M., Melack, J. M., Amaral, J. H. F., Maclntyre, S., Kasper, D., Cortés, A., ... Forsberg, B. R. (2020). Dissolved methane concentrations and fluxes to the atmosphere from a tropical floodplain lake. Biogeochemistry. doi: 10.1007/s10533-02000650-1 
Barros, D. J., de Souza Bento, M., de Souza Ferreira, M., Braga do Carmo, J., Hartung Toppa, R., Neu, V., ... Aparecido Navarrete, A. (2020). Methane, Microbes and Models in Amazonian Floodplains: State of the Art and Perspectives. In Changing Ecosystems and Their Services. doi: 10.5772/intechopen.90247

Bridgham, S. D., Cadillo-Quiroz, H., Keller, J. K., \& Zhuang, Q. (2013). Methane emissions from wetlands: Biogeochemical, microbial, and modeling perspectives from local to global scales. Global Change Biology, 19(5), 1325-1346. doi: 10.1111/gcb.12131

Callahan, B. J., McMurdie, P. J., Rosen, M. J., Han, A. W., Johnson, A. J. A., \& Holmes, S. P. (2016). DADA2: High-resolution sample inference from Illumina amplicon data. Nature Methods, 13(7), 581-583. doi: 10.1038/nmeth.3869

Camargo, O. A., Moniz, A. C., Jorge, J. A., \& Valadares, J. M. A. (2009). Métodos de análise química, mineralógica e física de solos do Instituto Agronômico de Campinas. Boletim Técnico, 106, 77.

Caporaso, J. G., Lauber, C. L., Walters, W. A., Berg-Lyons, D., Lozupone, C. A., Turnbaugh, P. J., ... Knight, R. (2011). Global patterns of 16 S rRNA diversity at a depth of millions of sequences per sample. Proceedings of the National Academy of Sciences of the United States of America, 108(1), 4516-4522. doi: 10.1073/pnas.1000080107

Conrad, R. (2009). The global methane cycle: Recent advances in understanding the microbial processes involved. Environmental Microbiology Reports, Vol. 1, pp. 285-292. doi: $10.1111 / \mathrm{j} .1758-2229.2009 .0$

Conrad, R., Klose, M., Claus, P., \& Enrich-Prast, A. (2010). Methanogenic pathway, 13C isotope fractionation, and archaeal community composition in the sediment of two clear-water lakes of Amazonia. Limnology and Oceanography, 55(2), 689-702. doi: 10.4319/lo.2009.55.2.0689

Conrad, R., Noll, M., Claus, P., Klose, M., Bastos, W. R., \& Enrich-Prast, A. (2011). Stable carbon isotope discrimination and microbiology of methane formation in tropical anoxic lake sediments. Biogeosciences, 8(3), 795-814. doi: 10.5194/bg-8-795-2011 
485

486

487

488

489

490

491

492

493

494

495

496

497

498

499

500

501

502

503

504

505

506

507

508

509

510

Costello, A. M., \& Lidstrom, M. E. (1999). Molecular characterization of functional and phylogenetic genes from natural populations of methanotrophs in lake sediments. Applied and Environmental Microbiology, 65(11), 5066-5074. doi: 10.1128/aem.65.11.5066-5074.1999

Cui, M., Ma, A., Qi, H., Zhuang, X., \& Zhuang, G. (2015). Anaerobic oxidation of methane: An "active" microbial process. MicrobiologyOpen, Vol. 4, pp. 1-11. doi: 10.1002/mbo3.232

Dedysh, S. N., Haupt, E. S., \& Dunfield, P. F. (2016). Emended description of the family Beijerinckiaceae and transfer of the genera Chelatococcus and Camelimonas to the family Chelatococcaceae fam. nov. International Journal of Systematic and Evolutionary Microbiology, 66(8), 3177-3182. doi: 10.1099/ijsem.0.001167

Dedysh, S. N., Knief, C., \& Dunfield, P. F. (2005). Methylocella species are facultatively methanotrophic. Journal of Bacteriology, 187(13), 4665-4670. doi: 10.1128/JB.187.13.4665-4670.2005

Dinno, A. (2017). dunn.test: Dunn's Test of Multiple Comparisons Using Rank Sums. R package version 1.3.5.

Eller, G., Krüger, M., \& Frenzel, P. (2005). Comparing field and microcosm experiments: A case study on methano- and methylo-trophic bacteria in paddy soil. FEMS Microbiology Ecology, 51(2), 279-291. doi: 10.1016/j.femsec.2004.09.007

Ettwig, K. F., Butler, M. K., Le Paslier, D., Pelletier, E., Mangenot, S., Kuypers, M. M. M., ... Strous, M. (2010). Nitrite-driven anaerobic methane oxidation by oxygenic bacteria. Nature, 464(7288), 543-548. doi: 10.1038/nature08883

Evans, P. N., Boyd, J. A., Leu, A. O., Woodcroft, B. J., Parks, D. H., Hugenholtz, P., \& Tyson, G. W. (2019). An evolving view of methane metabolism in the Archaea. Nature Reviews Microbiology, Vol. 17, pp. 219-232. doi: 10.1038/s41579-018-0136-7

Evans, P. N., Parks, D. H., Chadwick, G. L., Robbins, S. J., Orphan, V. J., Golding, S. D., \& Tyson, G. W. (2015). Methane metabolism in the archaeal phylum Bathyarchaeota 
revealed by genome-centric metagenomics. Science, 350(6259), 434-438. doi: 10.1126/science.aac7745

513

514

515

516

517

518

519

520

521

522

523

524

525

526

527

528

529

530

531

532

533

534

535

536

Fournier, G. (2009). Horizontal gene transfer and the evolution of methanogenic pathways. Methods in Molecular Biology (Clifton, N.J.), Vol. 532, pp. 163-179. doi: 10.1007/9781-60327-853-9_9

Gabriel, G. V. M., Oliveira, L. C., Barros, D. J., Bento, M. S., Neu, V., Toppa, R. H., ... Navarrete, A. A. (2020). Methane emission suppression in flooded soil from Amazonia. Chemosphere, 250. doi: 10.1016/j.chemosphere.2020.126263

Gedney, N., Huntingford, C., Comyn-Platt, E., \& Wiltshire, A. (2019). Significant feedbacks of wetland methane release on climate change and the causes of their uncertainty. Environmental Research Letters, 14(8). doi: 10.1088/1748-9326/ab2726

Graf, J. S., Mayr, M. J., Marchant, H. K., Tienken, D., Hach, P. F., Brand, A., ... Milucka, J. (2018). Bloom of a denitrifying methanotroph, 'Candidatus Methylomirabilis limnetica', in a deep stratified lake. Environmental Microbiology, 20(7), 2598-2614. doi: 10.1111/1462-2920.14285

Gregoris, T. B., Aldred, N., Clare, A. S., \& Burgess, J. G. (2011). Improvement of phylum- and class-specific primers for real-time PCR quantification of bacterial taxa. Journal of Microbiological Methods, 86(3), 351-356. doi: 10.1016/j.mimet.2011.06.010

Harrell, F. E. (2019). Hmisc: Harrell Miscellaneous. R package version 4.1-1.

He, Y., Li, M., Perumal, V., Feng, X., Fang, J., Xie, J., ... Wang, F. (2016). Genomic and enzymatic evidence for acetogenesis among multiple lineages of the archaeal phylum Bathyarchaeota widespread in marine sediments. Nature Microbiology. doi: 10.1038/nmicrobiol.2016.35

Hernández, M., Klose, M., Claus, P., Bastviken, D., Marotta, H., Figueiredo, V., ... Conrad, R. (2019). Structure, function and resilience to desiccation of methanogenic microbial communities in temporarily inundated soils of the Amazon rainforest (Cunia Reserve, 
Rondonia). Environmental Microbiology, 21(5), 1702-1717. doi: 10.1111/14622920.14535

Hess, L. L., Melack, J. M., Affonso, A. G., Barbosa, C., Gastil-Buhl, M., \& Novo, E. M. L. M. (2015). Wetlands of the Lowland Amazon Basin: Extent, Vegetative Cover, and Dualseason Inundated Area as Mapped with JERS-1 Synthetic Aperture Radar. Wetlands, 35(4), 745-756. doi: 10.1007/s13157-015-0666-y

Ho, A., Kerckhof, F. M., Luke, C., Reim, A., Krause, S., Boon, N., \& Bodelier, P. L. E. (2013). Conceptualizing functional traits and ecological characteristics of methane-oxidizing bacteria as life strategies. Environmental Microbiology Reports, 5(3), 335-345. doi: 10.1111/j.1758-2229.2012.00370.x

Holmes, A. J., Costello, A., Lidstrom, M. E., \& Murrell, J. C. (1995). Evidence that participate methane monooxygenase and ammonia monooxygenase may be evolutionarily related. FEMS Microbiology Letters, 132(3), 203-208. doi: 10.1016/03781097(95)00311-R

Ji, Y., Angel, R., Klose, M., Claus, P., Marotta, H., Pinho, L., ... Conrad, R. (2016). Structure 553 and function of methanogenic microbial communities in sediments of Amazonian lakes with different water types. Environmental Microbiology. doi: 10.1111/1462-2920.13491

Junk, W. J. (1997). The central Amazon floodplain: ecology of a pulsing system. In The central Amazon floodplain: ecology of a pulsing system.

Junk, W. J., Piedade, M. T. F., Schöngart, J., Cohn-Haft, M., Adeney, J. M., \& Wittmann, F.

Kay, M. and J. O. Wobbrock (2018). ARTool: Aligned Rank Transform for Nonparametric Factorial ANOVAs. R package version 0.10.5.

561 Klindworth, A., Pruesse, E., Schweer, T., Peplies, J., Quast, C., Horn, M., \& Glöckner, F. O. 
next-generation sequencing-based diversity studies. Nucleic Acids Research, 41(1). doi: $10.1093 /$ nar/gks808

Knief, C. (2015). Diversity and habitat preferences of cultivated and uncultivated aerobic methanotrophic bacteria evaluated based on pmoA as molecular marker. Frontiers in Microbiology, 6, 1346, doi: 10.3389/fmicb.2015.01346

Koschorreck, M. (2000). Methane turnover in exposed sediments of an Amazon floodplain lake. Biogeochemistry. doi: 10.1023/A:1006326018597

Krause, S., Lüke, C., \& Frenzel, P. (2012). Methane source strength and energy flow shape methanotrophic communities in oxygen-methane counter-gradients. Environmental Microbiology Reports, 4(2), 203-208. doi: 10.1111/j.1758-2229.2011.00322.x

Lammel, D. R., Feigl, B. J., Cerri, C. C., \& Nüsslein, K. (2015). Specific microbial gene abundances and soil parameters contribute to $\mathrm{C}, \mathrm{N}$, and greenhouse gas process rates after land use change in Southern Amazonian Soils. Frontiers in Microbiology, 6(OCT). doi: $10.3389 /$ fmicb.2015.01057

Leu, A. O., Cai, C., Mcllroy, S. J., Southam, G., Orphan, V. J., Yuan, Z., ... Tyson, G. W. (2020). Anaerobic methane oxidation coupled to manganese reduction by members of the Methanoperedenaceae. ISME Journal, 14(4), 1030-1041. doi: 10.1038/s41396020-0590-x

Lindsay, W. L., \& Norvell, W. A. (1978). Development of a DTPA Soil Test for Zinc, Iron, Manganese, and Copper. Soil Science Society of America Journal. doi: 10.2136/sssaj1978.03615995004200030009x

Liu, X., Li, M., Castelle, C. J., Probst, A. J., Zhou, Z., Pan, J., ... Gu, J. D. (2018). Insights into the ecology, evolution, and metabolism of the widespread Woesearchaeotal lineages. Microbiome, 6(1). doi: 10.1186/s40168-018-0488-2

Lyu, Z., Shao, N., Akinyemi, T., \& Whitman, W. B. (2018). Methanogenesis. Current Biology, 28, R727-R732. doi: 10.1016/j.cub.2018.05.021 
589

590

591

592

593

594

595

596

597

598

599

600

601

602

603

604

605

606

607

608

609

610

611

612

613

614

615

Ma, K., \& Lu, Y. (2011). Regulation of microbial methane production and oxidation by intermittent drainage in rice field soil. FEMS Microbiology Ecology, 75(3), 446-456. doi: 10.1111/j.1574-6941.2010.01018.x

Malyan, S. K., Bhatia, A., Kumar, A., Gupta, D. K., Singh, R., Kumar, S. S., ... Jain, N. (2016). Methane production, oxidation and mitigation: A mechanistic understanding and comprehensive evaluation of influencing factors. Science of the Total Environment, Vol. 572, pp. 874-896. doi: 10.1016/j.scitotenv.2016.07.182

Meyer, A. F., Lipson, D. A., Martín, A. P., Schadt, C. W., \& Schmidt, S. K. (2004). Molecular and Metabolic Characterization of Cold-Tolerant Alpine Soil Pseudomonas Sensu Stricto. Applied and Environmental Microbiology, 70(1), 483-489. doi: 10.1128/AEM.70.1.483-489.2004

Meyer, K. M., Klein, A. M., Rodrigues, J. L. M., Nüsslein, K., Tringe, S. G., Mirza, B. S., ... Bohannan, B. J. M. (2017). Conversion of Amazon rainforest to agriculture alters community traits of methane-cycling organisms. Molecular Ecology, 26(6), 1547-1556. doi: $10.1111 / \mathrm{mec} .14011$

Moreira-Turcq, P., Seyler, P., Guyot, J. L., \& Etcheber, H. (2003). Exportation of organic carbon from the Amazon River and its main tributaries. Hydrological Processes, 17(7), 1329-1344. doi: 10.1002/hyp.1287

Moura, J. M. S., Martens, C. S., Moreira, M. Z., Lima, R. L., Sampaio, I. C. G., Mendlovitz, H. P., \& Menton, M. C. (2008). Spatial and seasonal variations in the stable carbon isotopic composition of methane in stream sediments of eastern Amazonia. Tellus, Series B: Chemical and Physical Meteorology, 60B(1), 21-31. doi: 10.1111/j.16000889.2007.00322.x

Nazaries, L., Murrell, J. C., Millard, P., Baggs, L., \& Singh, B. K. (2013). Methane, microbes and models: Fundamental understanding of the soil methane cycle for future predictions. Environmental Microbiology, 15, 2395-2417. doi: 10.1111/14622920.12149 
Nkamga, V. D., \& Drancourt, M. (2016). Methanomassiliicoccales. In Bergey's Manual of

Systematics of Archaea

Oksanen, J., Guillaume Blanchet, F., Friendly, M., Kindt, R., Legendre, P., McGlinn, D., ... \&

Padilla, C. C., Bristow, L. A., Sarode, N., Garcia-Robledo, E., Gómez Ramírez, E., Benson, C. R., ... Stewart, F. J. (2016). NC10 bacteria in marine oxygen minimum zones. ISME Journal, 10(8), 2067-2071. doi: 10.1038/ismej.2015.262

Pangala, S. R., Enrich-Prast, A., Basso, L. S., Peixoto, R. B., Bastviken, D., Hornibrook, E. R. C., ... Gauci, V. (2017). Large emissions from floodplain trees close the Amazon methane budget. Nature, 552(7684), 230-234. doi: 10.1038/nature24639

Paula, F. S., Rodrigues, J. L. M., Zhou, J., Wu, L., Mueller, R. C., Mirza, B. S., ... Pellizari, V. H. (2014). Land use change alters functional gene diversity, composition and

Potter, C., Melack, J. M., \& Engle, D. (2014). Modeling methane emissions from amazon floodplain ecosystems. Wetlands, 34(3), 501-511. doi: 10.1007/s13157-014-0516-3

Ringeval, B., Houweling, S., Van Bodegom, P. M., Spahni, R., Van Beek, R., Joos, F., \& Röckmann, T. (2014). Methane emissions from floodplains in the Amazon Basin: Challenges in developing a process-based model for global applications. Biogeosciences, 11(6), 1519-1558. doi: 10.5194/bg-11-1519-2014 Nus̈slein, K. (2013). Conversion of the Amazon rainforest to agriculture results in biotic homogenization of soil bacterial communities. Proceedings of the National Academy of Sciences of the United States of America, 110(3), 988-993. doi: 10.1073/pnas. 1220608110 
643 RStudio Team. (2018). RStudio: Integrated development for R. Retrieved from http://www.rstudio.com/

645

646

647

648

649

650

651

652

653

654

655

656

657

658

659

660

661

662

663

664

665

666

667

668

669

Sawakuchi, H. O., Bastviken, D., Sawakuchi, A. O., Krusche, A. V., Ballester, M. V. R., \& Richey, J. E. (2014). Methane emissions from Amazonian Rivers and their contribution to the global methane budget. Global Change Biology, 20(9), 2829-2840. doi: 10.1111/gcb.12646

Sawakuchi, H. O., Bastviken, D., Sawakuchi, A. O., Ward, N. D., Borges, C. D., Tsai, S. M., ... Krusche, A. V. (2016). Oxidative mitigation of aquatic methane emissions in large Amazonian rivers. Global Change Biology, 22(3), 1075-1085. doi: 10.1111/gcb.13169

Scheller, S., Ermler, U., \& Shima, S. (2020). Catabolic Pathways and Enzymes Involved in Anaerobic Methane Oxidation. In Anaerobic Utilization of Hydrocarbons, Oils, and Lipids (pp. 31-59). doi: 10.1007/978-3-319-50391-2_3

Scheller, S., Yu, H., Chadwick, G. L., McGlynn, S. E., \& Orphan, V. J. (2016). Artificial electron acceptors decouple archaeal methane oxidation from sulfate reduction. Science, 351(6274), 703-707. doi: 10.1126/science.aad7154

Serrano-Silva, N., Sarria-Guzmán, Y., Dendooven, L., \& Luna-Guido, M. (2014). Methanogenesis and Methanotrophy in Soil: A Review. Pedosphere, 24(3), 291-307. doi: 10.1016/S1002-0160(14)60016-3

Shen, L. D., Wu, H. S., Gao, Z. Q., Liu, X., \& Li, J. (2016). Comparison of community structures of candidatus methylomirabilis oxyfera-like bacteria of NC10 phylum in different freshwater habitats. Scientific Reports, 6. doi: 10.1038/srep25647

Stahl D. A., \& Amann, R. (1991). Development and application of nucleic acid probes in bacterial systematics. In Nucleic Acid Techniques in Bacterial Systematics, 205-248.

Steinberg, L. M., \& Regan, J. M. (2008). Phylogenetic comparison of the methanogenic communities from an acidic, oligotrophic fen and an anaerobic digester treating municipal wastewater sludge. Applied and Environmental Microbiology, 74(21), 66636671. doi: 10.1128/AEM.00553-08 
Su, G., Zopfi, J., Yao, H., Steinle, L., Niemann, H., \& Lehmann, M. F. (2019). Manganese/ironsupported sulfate-dependent anaerobic oxidation of methane by archaea in lake sediments. Limnology and Oceanography. doi: 10.1002/Ino.11354

Timmers, P. H. A., Welte, C. U., Koehorst, J. J., Plugge, C. M., Jetten, M. S. M., \& Stams, A. J. M. (2017). Reverse Methanogenesis and Respiration in Methanotrophic Archaea. Archaea, Vol. 2017. doi: 10.1155/2017/1654237

Venturini, A. M., Nakamura, F. M., Gontijo, J. B., França, A. G., Yoshiura, C. A., Mandro, J. A. \& Tsai, S. M. (2020). Robust DNA protocols for tropical soils. Heliyon. Accepted to publication.

Wei, T., \& Simko, V. (2017). corrplot. R Package, v. 0.84.

Welander, P. V., \& Metcalf, W. W. (2008). Mutagenesis of the C1 oxidation pathway in Methanosarcina barkeri: New insights into the Mtr/Mer bypass pathway. Journal of Bacteriology, 190(6), 1928-1936. doi: 10.1128/JB.01424-07

Wickham, H., \& Chang, W. (2016). ggplot2': Create Elegant Data Visualisations Using the Grammar of Graphics. R package version 3.1.0.

Wilson, C., Gloor, M., Gatti, L. V., Miller, J. B., Monks, S. A., McNorton, J., ... Chipperfield, M. P. (2016). Contribution of regional sources to atmospheric methane over the Amazon Basin in 2010 and 2011. Global Biogeochemical Cycles, 30(3), 400-420. doi: $10.1002 / 2015 G B 005300$

Yan, Z., \& Ferry, J. G. (2018). Electron bifurcation and confurcation in methanogenesis and reverse methanogenesis. Frontiers in Microbiology, Vol. 9 . doi: 10.3389/fmicb.2018.01322

Ye, F., Ma, M. H., Op den Camp, H. J. M., Chatzinotas, A., Li, L., Lv, M. Q., .. Wang, Y. (2018). Different Recovery Processes of Soil Ammonia Oxidizers from Flooding Disturbance. Microbial Ecology, 76(4), 1041-1052. doi: 10.1007/s00248-018-1183-3 
bioRxiv preprint doi: https://doi.org/10.1101/2020.05.04.076356; this version posted May 4, 2020. The copyright holder for this preprint

(which was not certified by peer review) is the author/funder, who has granted bioRxiv a license to display the preprint in perpetuity. It is made available under aCC-BY-ND 4.0 International license.

695 Yu, Y., Lee, C., \& Hwang, S. (2005). Analysis of community structures in anaerobic processes

696

using a quantitative real-time PCR method. Water Science and Technology, 52(1-2),

697

85-91. doi: 10.2166/wst.2005.0502 


\section{Tables}

699

700 Table 1. Analysis of Similarity of the microbial communities in the floodplain sediments and 701 upland forest soils.

\begin{tabular}{ccccc}
\hline \multirow{2}{*}{ Area } & \multicolumn{2}{c}{ Archaea } & \multicolumn{2}{c}{ Bacteria } \\
& $\mathrm{R}$ & $\mathrm{p}$-value & $\mathrm{R}$ & $\mathrm{p}$-value \\
\hline All samples & $\mathbf{0 . 6 5 5 4}$ & $\mathbf{0 . 0 0 1}$ & $\mathbf{0 . 8 9 2 5}$ & $\mathbf{0 . 0 0 1}$ \\
Season comparison & & & & \\
FP1 & -0.1852 & 0.900 & 0.8889 & 0.100 \\
FP2 & 0.2593 & 0.100 & 0.5926 & 0.100 \\
FP3 & 0.0000 & 0.900 & 0.1111 & 0.400 \\
PFO & -0.1852 & 0.900 & 0.1852 & 0.400 \\
Area comparison & & & & \\
FP1 vs. FP2 & 0.3148 & 0.057 & $\mathbf{0 . 8 4 5 7}$ & $\mathbf{0 . 0 0 1}$ \\
FP1 vs. FP3 & 0.2809 & 0.055 & $\mathbf{0 . 8 4 5 7}$ & $\mathbf{0 . 0 0 1}$ \\
FP2 vs. FP3 & 0.1698 & 0.140 & $\mathbf{0 . 6 2 9 6}$ & $\mathbf{0 . 0 0 1}$ \\
FP1 vs. PFO & $\mathbf{0 . 6 3 5 8}$ & $\mathbf{0 . 0 0 8}$ & $\mathbf{0 . 8 0 2 5}$ & $\mathbf{0 . 0 0 1}$ \\
FP2 vs. PFO & $\mathbf{0 . 6 7 9 0}$ & $\mathbf{0 . 0 0 2}$ & $\mathbf{0 . 7 9 6 3}$ & $\mathbf{0 . 0 0 1}$ \\
FP3 vs. PFO & $\mathbf{0 . 6 5 1 2}$ & $\mathbf{0 . 0 0 5}$ & $\mathbf{0 . 7 0 3 7}$ & $\mathbf{0 . 0 0 4}$ \\
\hline
\end{tabular}

702 FP1: Floodplain 1; FP2: Floodplain 2; FP3: Floodplain 3; PFO: Upland Forest. Bold values indicate 
704 Table 2. Two-way ANOVA of aligned rank transformed qPCR and sequencing data from the

705 floodplains.

\begin{tabular}{ccccccccccc}
\hline Data & \multicolumn{3}{c}{ Area } & \multicolumn{3}{c}{ Season } & \multicolumn{5}{c}{ Area x Season } \\
& $\mathrm{df}$ & $\mathrm{F}$ & $\mathrm{p}$ & $\mathrm{df}$ & $\mathrm{F}$ & $\mathrm{p}$ & $\mathrm{df}$ & $\mathrm{F}$ & $\mathrm{p}$ \\
\hline Gene quantification & & & & & & & & & \\
16S rRNA Archaea & 2,12 & 3.745 & 0.055 & 1,12 & 4.708 & 0.051 & 2,12 & 4.401 & $\mathbf{0 . 0 3 7}$ \\
16S rRNA Bacteria & 2,12 & 3.843 & 0.051 & 1,12 & 13.286 & $\mathbf{0 . 0 0 3}$ & 2,12 & 0.406 & 0.675 \\
mcrA & 2,12 & 1.388 & 0.287 & 1,12 & 0.001 & 0.971 & 2,12 & 0.180 & 0.837 \\
pmoA & 2,12 & 0.013 & 0.987 & 1,12 & 8.768 & $\mathbf{0 . 0 1 2}$ & 2,12 & 0.056 & 0.945 \\
Ratio mcrA:pmoA & 2,12 & 2.439 & 0.129 & 1,12 & 3.314 & 0.094 & 2,12 & 0.502 & 0.618 \\
Methanogenic taxa & & & & & & & & & \\
Total & 2,12 & 12.590 & $\mathbf{0 . 0 0 1}$ & 1,12 & 0.676 & 0.427 & 2,12 & 2.957 & 0.090 \\
Methanobacteriaceae & 2,12 & 12.195 & $\mathbf{0 . 0 0 1}$ & 1,12 & 0.439 & 0.520 & 2,12 & 2.152 & 0.159 \\
Methanomassiliicoccaceae & 2,12 & 3.083 & 0.083 & 1,12 & 1.961 & 0.187 & 2,12 & 1.104 & 0.363 \\
Methanoperedenaceae & 2,12 & 7.861 & $\mathbf{0 . 0 0 7}$ & 1,12 & 12.009 & $\mathbf{0 . 0 0 5}$ & 2,12 & 6.460 & $\mathbf{0 . 0 1 2}$ \\
Methanosarcinaceae & 2,12 & 2.715 & 0.106 & 1,12 & 10.269 & $\mathbf{0 . 0 0 8}$ & 2,12 & 17.570 & $<0.001$ \\
Methanotrophic taxa & & & & & & & & & \\
Total & 2,12 & 1.093 & $\mathbf{0 . 3 6 6}$ & 1,12 & 0.240 & 0.633 & 2,12 & 0.138 & 0.872 \\
Beijerinckiaceae & 2,12 & 0.089 & 0.915 & 1,12 & 0.125 & 0.729 & 2,12 & 0.033 & 0.968 \\
Methylococcaceae & 2,12 & 0.969 & 0.407 & 1,12 & 2.618 & 0.132 & 2,12 & 0.973 & 0.406 \\
Methylomonaceae & 2,12 & 4.096 & $\mathbf{0 . 0 4 4}$ & 1,12 & 8.133 & $\mathbf{0 . 0 1 5}$ & 2,12 & 6.706 & $\mathbf{0 . 0 1 1}$ \\
NC10 & 2,12 & 1.705 & 0.223 & 1,12 & 0.245 & 0.630 & 2,12 & 2.748 & 0.104 \\
\hline
\end{tabular}

706 df: degrees of freedom, F: F-values, $p: p$-values. Bold values indicate statistical significance at $p$ 707 value $<0.05$ 


\section{Figures}

709

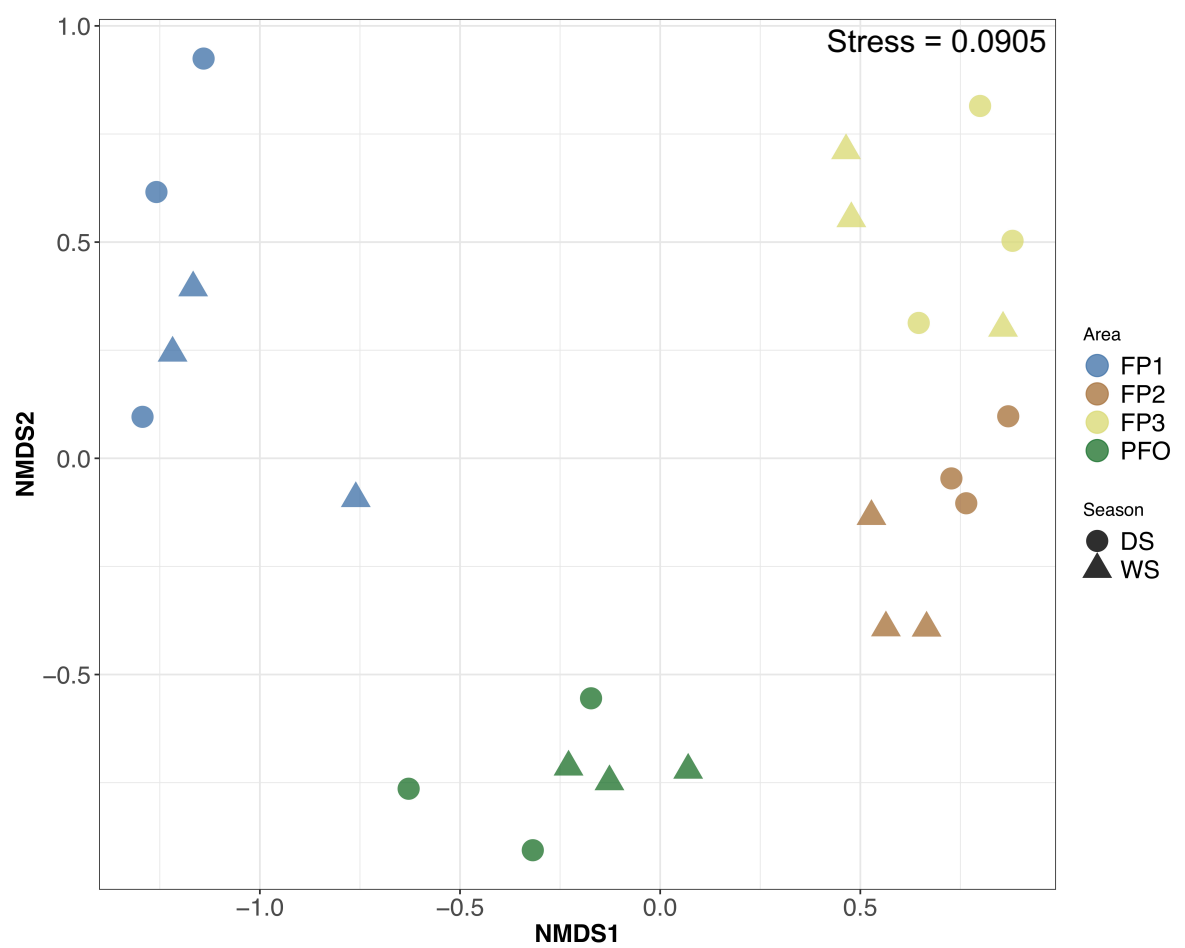

711 Figure 1. Clustering of the chemical properties of the floodplain sediments (FP1, FP2 and FP3) and upland forest soils (PFO) during wet (WS) and dry (DS) seasons. Plot is based on non-metric multidimensional scaling (NMDS) using the Euclidean distance index. 

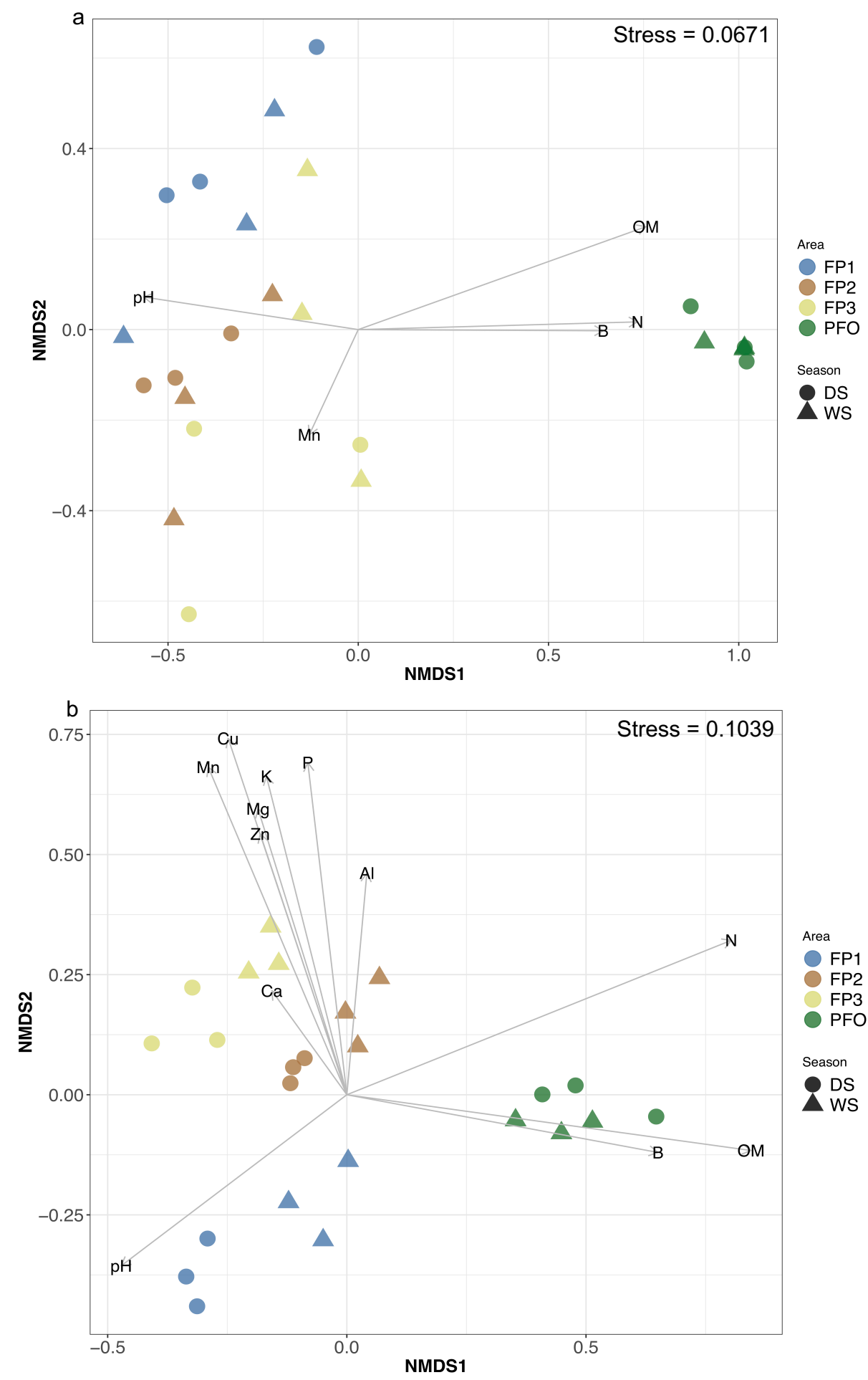

Figure 2. Clustering of the archaeal (a) and bacterial (b) communities in the floodplain sediments (FP1, FP2 and FP3) and upland forest soils (PFO) during wet (WS) and dry (DS) seasons, and correlation with environmental factors. Only environmental factors that share significant correlation $(p<0.05)$ with community structure are displayed with vectors: Al, aluminium; B: boron; $\mathrm{Ca}$, calcium; $\mathrm{Cu}$ : cupper; $\mathrm{K}$ : potassium; $\mathrm{Mg}$ : magnesium; $\mathrm{Mn}$ : manganese; N: nitrogen; OM: organic matter; P: phosphorus; $\mathrm{pH}$ : hydrogen potential; Zn: zinc. Plot is based on non-metric multidimensional scaling (NMDS) using the Bray-Curtis distance index. 
bioRxiv preprint doi: https://doi.org/10.1101/2020.05.04.076356; this version posted May 4, 2020. The copyright holder for this preprint (which was not certified by peer review) is the author/funder, who has granted bioRxiv a license to display the preprint in perpetuity. It is made available under aCC-BY-ND 4.0 International license.
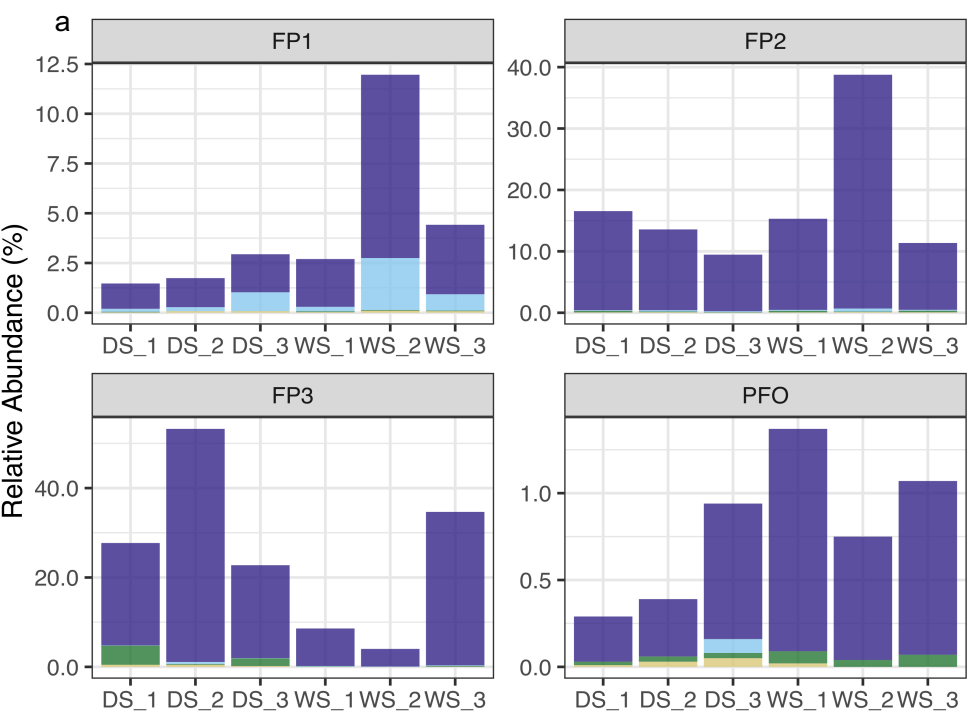

\section{Methanogens}

Methanobacteriaceae

Methanomassiliicoccaceae

Methanoperedenaceae

Methanosarcinaceae
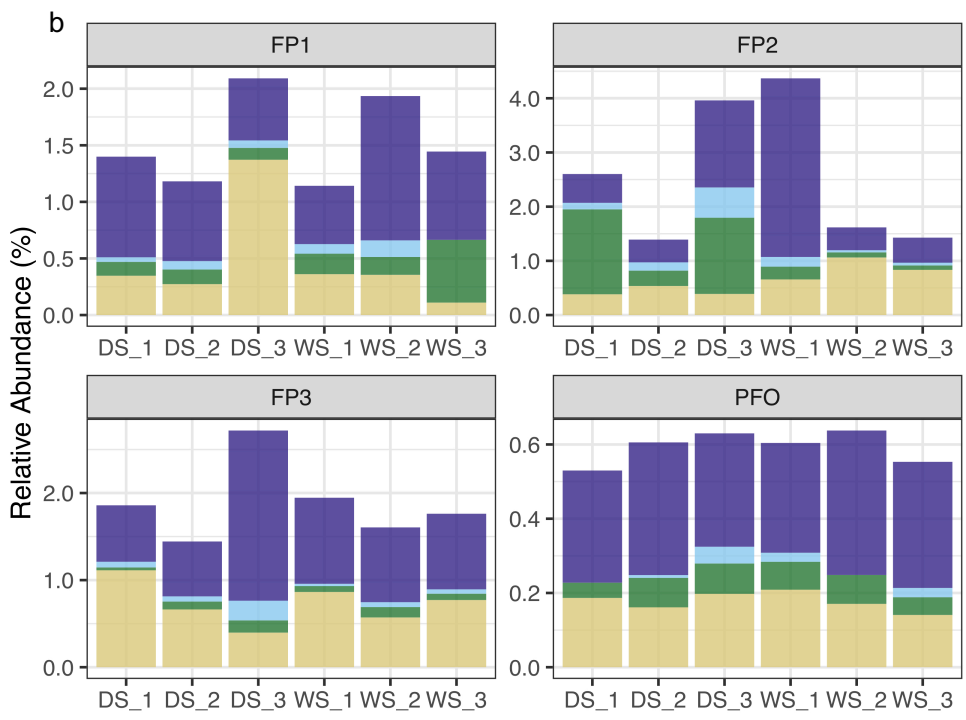

Methanotrophs

Beijerinckiaceae

Methylococcaceae

Methylomonaceae

NC10

Figure 3. Relative abundance from of methanogenic (a) and methanotrophic (b) taxa in the dry (DS) seasons. 

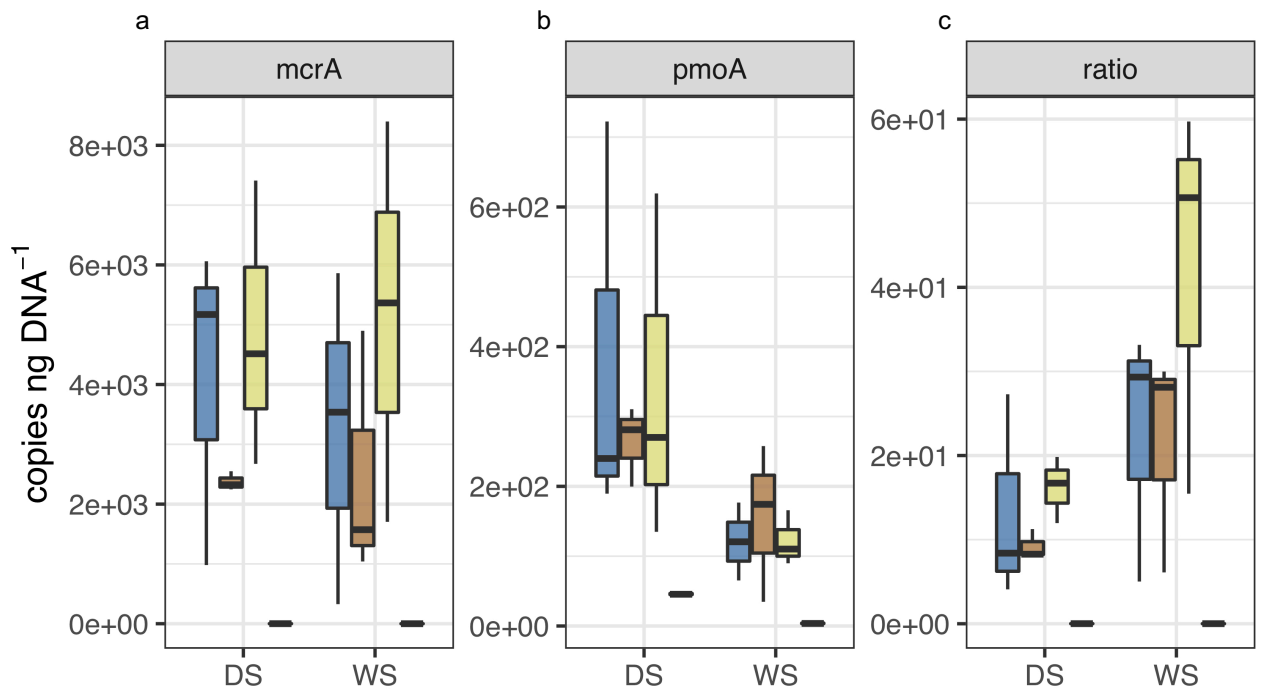

Area

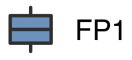

官 FP2

它 FP3

官 PFO

Figure 4. Number of copies per ng of DNA (copies ng DNA ${ }^{-1}$ ) of $m c r A(a)$, pmoA (b) genes, and mcrA:pmoA ratio (c) in the floodplain sediments (FP1, FP2 and FP3) and upland forest soils (PFO) during wet (WS) and dry (DS) seasons. 


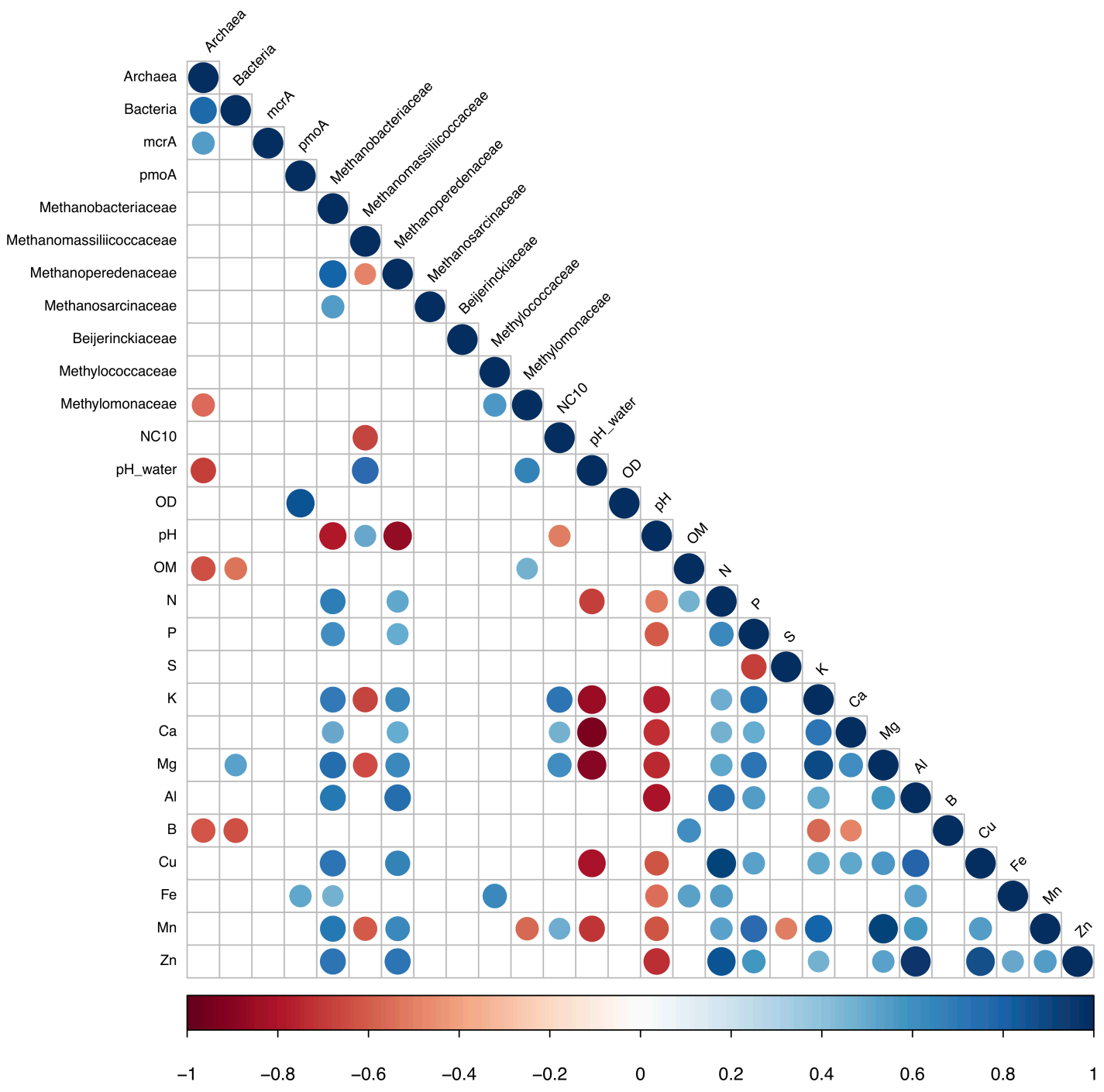

736 Figure 5. Spearman's correlations between the abundance of $16 \mathrm{~S}$ rRNA and $\mathrm{CH}_{4}$ marker genes, methanogenic and methanotrophic taxa and chemical properties in the floodplain (FP1, FP2 and FP3) sediments. Significant correlations $(p<0.05)$ are marked in blue (positive) and in red (negative). Circle size is proportional to the $\mathrm{R}^{2}$ value. 